\title{
ARKEOLOGI FORENSIK: PERKEMBANGAN DAN CAPAIANNYA DI INDONESIA
}

\section{FORENSIC ARCHAEOLOGY: ITS DEVELOPMENT AND ACHIEVEMENT IN INDONESIA}

\author{
Rusyad Adi Suriyanto ${ }^{11}$ \\ ${ }^{1}$ Laboratorium Bioantropologi dan Paleoantropologi Fakultas Kedokteran \\ Universitas Gadjah Mada \\ rusyad suriyanto@yahoo.co.id
}

\begin{abstract}
Forensic archeology is defined as the application of archaeological principles and techniques in medico-legal and/or humanity context related to buried evidence. Forensic archaeologist has two roles, as the expert who unearth buried objects systematically and reconstruct them. This paper discusses the role of archeology and archaeologists in the excavation of criminal, humanitarian and disaster victims. Archaeologist's role to reveal paleoanthropological materials smuggled and theft is also discussed in this paper. Humanitarian missions to investigate mass grave of victims of war, political strife and genocide in the past and the present are other archaeologist's role discussed in this paper.

The existence, condition and development of forensic archaeology in Indonesia emphasize the significance of new paradigm in Indonesian archaeology. Forensic archeology not merely focusess on the study of cultural materials of the past, education and museum development, cultural resource management and its advocacy, but it also has role in medico-legal works. Forensic archaeologist also engages in disaster victim identification (DVI) that addresses issues related to victims buried by either natural or human disasters.
\end{abstract}

Keywords: Archaeology, Bioarchaeology, Forensic Archaeology, Indonesia

\begin{abstract}
ABSTRAK
Arkeologi forensik didefinisikan sebagai penerapan prinsip-prinsip dan teknik-teknik arkeologis dalam konteks medico-legal dan/atau dalam konteks kemanusiaan yang berkaitan dengan bukti-bukti terkubur. Ahli arkeologi forensik berperan sebagai ahli yang mampu menemukan benda-benda yang terkubur secara sistematis dan merekonstruksi apa yang mereka temukan itu. Makalah ini mendiskusikan peran arkeologi dan para arkeolog dalam ekskavasi korban-korban kriminal, kemanusiaan dan bencana. Makalah ini berusaha melihat apa yang telah mereka kerjakan meliputi pembuktian kasus-kasus penyelundupan dan pencurian material-material paleoantropologis, dan keterlibatan dalam misi-misi kemanusian untuk penyelidikan dan pengungkapan korban-korban kubur massal akibat perang, pertikaian politik dan genosida di masa lalu dan masa kini.

Keberadaan, kondisi dan perkembangan arkeologi forensik di Indonesia menegaskan pentingnya pengembangan paradigma baru dalam arkeologi Indonesia. Arkeologi tidak semata berkonsentrasi pada kajian material-material budaya masa lalu, pendidikan dan pengembangan museum, manajemen dan advokasi sumberdaya budaya, namun juga berperan untuk pekerjaan medico-legal. Ahli arkeologi forensik bahkan terlibat dalam disaster victim identification (DVI) yang menangani masalah-masalah yang berkaitan dengan para korban yang terkubur oleh beragam bencana baik yang diakibatkan oleh alam maupun manusia.
\end{abstract}

Kata kunci: Arkeologi, Bioarkeologi, Arkeologi Forensik, Indonesia.

\footnotetext{
1 Merupakan makalah yang disempurnakan dari presentasi dalam Diskusi IImiah Arkeologi "Integrasi Pengembangan Arkeologi Indonesia" oleh Ikatan Ahli Arkeologi Indonesia (IAAI) Komisariat Daerah DI Yogyakarta dan Jawa Tengah pada 25 Juni 2014, di Museum Benteng Vredeburg, Yogyakarta.
}

Tanggal masuk : :10 Mei 2016

Tanggal diterima :31 Mei 2016 


\section{PENDAHULUAN}

Sebagian dari kita mungkin tidak asing dengan istilah-istilah dokter (spesialis) forensik, patologi forensik, kedokteran gigi forensik, DNA forensik, entomologi forensik, psikologi forensik bahkan antropologi forensik. Ada satu bidang lagi yang berkaitan dengan forensik yang masih asing bagi sebagian orang termasuk mahasiswa arkeologi, yaitu arkeologi forensik. Berkaitan dengan keberadaan bidang ilmu ini ada beberapa pertanyaan yang sering saya tanyakan kepada para mahasiswa saya di Jurusan Arkeologi Fakultas IImu Budaya Universitas Gadjah Mada. Pertanyaan tersebut antara lain, apa yang saudara ketahui tentang arkeologi forensik? Apakah ada hubungan antara arkeologi dan ilmuilmu forensik itu? Bagaimana hubungan antara antropologi dan arkeologi forensik tersebut? Dan, pernahkah anda membaca atau mendengar bahwa seorang arkeolog berperan dalam mengungkap kasuskasus forensik di Indonesia? Pertanyaan-pertanyaan ini saya tanyakan kepada para mahasiswa tersebut, khususnya sejak setahun yang lalu, terutama pada saat saya mengajar mata kuliah Paleoantropologi dan Bioarkeologi di di jurusan tersebut.

Sama halnya dengan para mahasiswa arkeologi, masyarakat umum di Indonesia juga masih merasa asing dengan forensik sebagai bagian dari ilmu arkeologi. Mereka selalu mengaitkan profesi forensik dengan beberapa bencana dahsyat kemanusian yang pernah terjadi di negeri kita beberapa waktu yang lalu. Sebagai contoh, kecelakaan pesawat Silk Air pada tahun 1997 di Sumatera Selatan sampai Adam Air di perairan Laut Sulawesi dan Garuda Indonesia Airways di Yogyakarta pada tahun 2007. Kecelakaan pesawat terkini dengan korban seluruh penumpang dan awak pesawat adalah kecelakaan Sukhoi Superjet 100 (SSJ-100) di Gunung Salak pada 9 Mei 2012.

Musibah juga terjadi di lautan seperti hancur dan tenggelamnya kapal Senopati di perairan Laut Jawa pada tahun 2007. Kapal Motor Teratai Prima adalah kapal motor penumpang yang mengalami musibah di perairan Tanjung Baturoro, Sendana, Kabupaten Majene, Sulawesi Barat, pada 11 Januari 2009. Berdasarkan manifes kapal ini diketahui bahwa kapal ini mengangkut 267 orang penumpang termasuk sejumlah awak kapal dan nakhoda. Musibah tenggelamnya kapal di lautan terjadi pula pada kapal yang mengangkut 215 imigran gelap asal Timur Tengah yang akan menuju ke Australia di Trenggalek, Jawa Timur, pada 18 Desember 2011.

Musibah lain meliputi bencana tsunami di Aceh, Pulau Nias dan Pulau Simelue pada tahun 2004. Bencana gempa bumi di Pulau Flores pada tahun 1992, Yogjakarta dan Jawa Tengah pada tahun 2006, dan Sumatera Barat dan Bengkulu pada tahun 2007. Banjir dan tanah longsor terjadi di Kabupaten Karanganyar dan sekitarnya pada akhir tahun 2007.

Musibah juga terjadi oleh tindakan manusia atas manusia yang lain dengan motif-motif tertentu. Sebuah contoh dari musibah ini adalah kasus kriminalitas dengan memutilasi bagian-bagian badan korbannya. Kita masih teringat peristiwa "korban-korban Ryan", di mana pelaku telah membunuh 11 orang, 
yang satu jasad dimutilasi badannya dan dimasukkan dalam dua tas besar dan dibuang di Jakarta, serta 10 korban lain dan jasad-jasadnya dikubur di belakang rumah orang tuanya di Jombang di antara tahun $2007-2008$.

Musibah yang dapat membunuh secara massal, misalkan kasus pengeboman. Beberapa kali peristiwa ini terjadi pada selang waktu antara tahun 2002 sampai 2005, mulai Bom Bali 1 yang terjadi pada tahun 2002, dan disusul oleh Bom JW Marriot Jakarta pada tahun 2003, Bom Kedutaan Australia di Jakarta pada tahun 2004, serta terjadi lagi Bom Bali 2 pada tahun 2005. Jika menengok kasus-kasus forensik itu, lalu di mana posisi dan peran arkeologi forensik? Tentu saja tidak semua kasus forensik melibatkan kompetensi arkeologi forensik dan di situ lah kemudian arkeologi forensik menjadi istimewa. Makalah ini akan memaparkan batasan arkeologi forensik dan peran arkeologi forensik untuk penyelidikan-penyelidikan forensik. Selanjutnya, makalah ini akan memaparkan sejauh mana karya disiplin ini mampu membantu penyelidikan dan mengungkap kasus-kasus penyelundupan dan pencurian material-material paleoantropologis. Peran arkeologi forensik dalam misi-misi kemanusian untuk penyelidikan dan pengungkapan korban-korban kubur massal akibat perang, pertikaian politik dan genosida di masa lalu dan masa kini juga akan dibahas dalam makalah ini termasuk bagaimana keberadaan, kondisi dan perkembangan arkeologi forensik di Indonesia. Makalah ini menegaskan pentingnya pengembangan paradigma baru untuk arkeologi Indonesia, yakni arkeologi yang tidak terfokus pada kajian benda-benda tinggalan manusia masa lampau, namun juga sisa-sisa hayat manusia manusia masa kini.

\section{ARKEOLOGI FORENSIK}

\begin{tabular}{lcr}
\multicolumn{2}{c}{ Arkeologi forensik adalah } \\
penerapan prinsip-prinsip dan \\
teknik-teknik & arkeologis dalam \\
penyelesaian & masalah-masalah \\
medico-legal, & yakni berkaitan
\end{tabular} dengan aspek medis dan hukum; bahkan ada yang menyebut sebagai penerapan suatu kombinasi teknikteknik arkeologis dan ilmu forensik, biasanya dalam kerangka penegakan hukum (Crist, 2001; Owsley, 2001; Hunter, 2002; Ferlini, 2007; Cox et al., 2008; Dupras et al., 2012; Litherland et al., 2008; Hunter et al., 2013). Dalam konteks ini, arkeologi forensik merujuk kepada pendekatan bioarkeologis, yakni pendekatan yang penting sebagai bagian integratif antropologi biologis dan arkeologi untuk merekonstruksi budaya masyarakat masa lampau. (Crist, 2001; Owsley, 2001; Hunter, 2002; Hunter \& Cox, 2005a; Ferlini, 2007; Dupras et al., 2012; Skinner et al., 2013; Schats et al., 2014). Selain antropologi forensik, arkeologi forensik adalah disiplin yang cepat berkembang dalam bidang arkeologi, yang dirancang untuk membantu pihak kepolisian dan aparat penegak hukum lain dengan berbagai keterampilan yang begitu khusus (Dirkmaat \& Adovasio, 1997; Hugland, 2001; Owsley, 2001; Scott \& Connor, 2001; Hunter, 2002; Skinner et al., 2003; Gould, 2004a; Gould, 2004b; Ferlini, 2007; Cox et al., 2008; Litherland et al., 2008; Davenport \& Harrison 2011; Dupras et al., 2012). Keterampilanketerampilan ini berkisar dari identifikasi sisa-sisa hayat dari lokasi-lokasi kubur klandestin, penggalian dan perekamannya yang 
cermat, dan memulihkan profil-profil biologis individu-individunya. Seorang arkeolog forensik selalu memastikan bahwa semua kerjanya mengikuti pedoman baku dan mempertahankan standar profesionalnya selama penyelidikan peristiwa forensik itu. Secara khusus, para arkeolog forensik mampu melakukan rekonstruksi terkontrol atas sisa-sisa manusia dan bukti-bukti lain dalam ranah forensik. Kepatutan prosedur arkeologis terhadap kebutuhan waktu dan perhatian terhadap detail selalu diutamakan, agar investigasi forensik dapat memenuhi kaidah prosedural dan tuntas. Hasil akhir dari upaya ini adalah kemampuan untuk merekonstruksi semirip mungkin seluruh adegan yang pernah terjadi sebelum dilakukan penggaliannya. Mereka berperan dalam survei, pencarian dan memastikan lokasinya, pemetaan dan penggambarannya, identifikasi tulang dan atributnya, dokumentasinya, rekonstruksinya, serta pernyataan dan kesanggupan sebagai saksi ahli (Skinner, 1987; Hoshower, 1998; Neave, 2000; Hugland, 2001; Owsley, 2001; Hochrein, 2002; Hunter, 2002; Duhig, 2003; Hunter \& Cox, 2005a, 2005b, 20005c; Jessee \& Skinner, 2005; Menez, 2005; Tuller \& Đurić, 2006; Bernardi \& Fondebrider, 2007; Cox et al., 2008; Dirkmaat et al., 2008; Cheetham \& Hanson, 2009; Holland \& Connell, 2009; Barone, 2012; Cabo et al., 2012; Dupras et al., 2012; Tuller, 2012; Hunter et al., 2013).

Aktivitas arkeologi forensik mula-mula berkembang di Amerika Serikat sebagai cabang dari antropologi forensik pada awal abad ke-19, ketika kepentingan atas sisasisa rangka manusia untuk identifikasi personal telah mendapat pengakuan (Scott \& Connor, 2001; Blau \& Ubelaker, 2009; Ubelaker, 2009; Byers, 2011; Gowland \& Thompson, 2013). Dua windu memasuki paruh kedua abad ke-20, para antropolog forensik menganjurkan perlunya informasi kontekstual yang dapat disediakan oleh para arkeolog tentang di mana dan bagaimana sisa-sisa rangka manusia itu ditemukan dalam kerangka untuk membantu identifikasi personal (Morse, et al., 1976; Morse, et al., 1983; SiglerEisenberg, 1985; Burn, 1999; Larsen, 2000; Scott \& Connor, 2001; Owsley, 2001; Hunter, 2002; Dirkmaat et al., 2008; Ubelaker, 2009; Byers, 2011). Kebutuhan untuk penggalian terkontrol oleh para profesional terlatih menjadi makin terbuka sebagai akibat dari meningkatnya jumlah kasus yang melibatkan sisa-sisa manusia yang terkubur yang tidak mampu dilanjutkan ke pengadilan akibat penggalian dilakukan oleh mereka yang tidak terampil (Owsley, 2001; Hunter, 2002; Dirkmaat et al., 2008; Ubelaker, 2009).

Berbeda dengan antropologi forensik yang memiliki sejarah mapan dan telah menjadi semakin populer sebagai akibat dari pemberitaan di media massa sejalan dengan makin meningkatnya permintaan lembaga nasional dan internasional untuk membantu identifikasi dalam ranah DVI (Disaster Victim Identification) untuk penegakkan hak-hak asasi manusia atas konflik dan perang di dalam suatu negara dan antar negara dalam beberapa tahun yang lalu, arkeologi forensik sebagai ilmu baru muncul sebagai konsekuensi atas penekanan terhadap pilihan untuk peminatan profesional di Amerika Utara dan Inggris (Morse, et al., 1976; Morse, et al., 1983; Galloway 
\& Simmons, 1997; Black, 2000; Thompson, 2001, 2003; Cox, 2009; Skinner \& Bowie, 2009; Wright \& Hanson, 2009; Byers, 2011). Berkaitan dengan perspektif historis, Cox (2009) dan Ubelaker (2009) juga menekankan mengapa arkeologi forensik lebih umum di Inggris dibandingkan di Amerika Serikat. Perspektif lain telah dikemukan oleh Scott \& Connor (2001) yang mengusulkan bahwa arkeologi forensik itu adalah antropologi forensik, dan antropologi forensik itu adalah osteologi forensik. Usulan itu merupakan tradisi yang telah berkembang di Eropa Timur (Jankauskas, 2009). Sebelum itu, usulan lain telah disampaikan oleh Lovis (1992), bahwa sebenarnya arkeologi forensik dapat mengembangkan aplikasi yang lebih luas sebagai mortuary anthropology.

Arkeologi telah membuktikan dirinya untuk menjadi alat ilmu forensik secara efektif, baik lokal, regional maupun internasional dengan penerapan metode-metode penelitiannya (Haglund, 2001; Hunter \& Cox, 2005a; Blau \& Ubelaker, 2009; Hunter, 2009; Steadman et al., 2009; Hunter et al., 2013). Arkeologi forensik telah berkembang selama 20 tahun terakhir dan sekarang menjadi suatu disiplin yang mantap, yang memberikan sumbangsih penting untuk penyelidikan-penyelidikan kriminal. Bukti-bukti dari penyelidikannya mampu mempengaruhi argumentasiargumentasi hukumnya di pengadilan. Para arkeolog forensik telah membantu dalam penyelidikan kasus pembunuhan domestik dan dalam bencana massal (Connor \& Scott, 2001; Haglund, 2001; Gould, 2004a; Gould, 2004b; Hunter \& Cox, 2005b; Hunter \& Cox, 2005c; Wright et al., 2005; Ellis, 2007; Ferlini, 2007; López \& Umańa, 2007; Cox et al., 2008; Blau \& Hill, 2009; Blau \& Ubelaker, 2009; Hochrein, 2009; Hunter, 2009; Steadman et al., 2009). Mereka juga telah berperan untuk menyelidiki genosida dan pelanggaran hak asasi manusia sejak pertengahan 1980-an (Connor \& Scott, 2001; Skinner et al., 2003; Juhl, 2005; Wright et al., 2005; Juhl \& Olsen, 2006; Bernardi \& Fondebrider, 2007; Ballbé \& Steadman, 2008; Schultz \& Dupras, 2008; Blau \& Ubelaker, 2009; Congram \& Sterenberg, 2009; Flavel \& Barker, 2009; Sterenberg, 2009; Ubelaker, 2009; Blau \& Fondebrider, 2010; Mark, 2010; Cabo et al., 2012; Crossland, 2013). Selama 20 tahun terakhir PBB dan organisasi-organisasi hak asasi manusia telah merekrut para arkeolog forensik untuk menggali kuburan individual dan massal yang terkait dengan penyelidikan pembunuhan politik, kejahatan perang dan genosida di lebih dari dua belas negara di seluruh dunia (Crossland, 2000; Connor \& Scott, 2001; Haglund et al., 2001; Stover \& Ryan 2001; Hunter \& Cox, 2005b; Wright et al., 2005; Skinner, 2007; Steel, 2008; Blau \& Ubelaker, 2009; Wright \& Hanson, 2009; Blau \& Fondebrider, 2010; Blau et al., 2011; Tuller, 2012; Kinsella \& Blau, 2013).

\section{KETERLIBATAN ARKEOLOGI UNTUK PENYELIDIKAN KASUS FORENSIK}

Arkeologi forensik adalah penerapan teknik dan metodologi, yang awalnya dikembangkan untuk tujuan penelitian arkeologi, khususnya untuk membantu penyelidikan hukum. Bahkan arkeologi forensik hanya dimungkinkan dengan penerapan 
metode-metode penelitian arkeologis, yakni ekskavasi dan identifikasi sisa-sisa biologis. Selama 20 tahun terakhir arkeologi forensik telah memainkan peran penting dalam sistem peradilan pidana di beberapa negara (Crist, 2001; Haglund, 2001; Owsley, 2001; Hunter, 2002; Hunter \& Cox, 2005a; Ferlini, 2007; Cox et al., 2008; ; Blau \& Ubelaker, 2009; Hunter, 2009; Steadman et al., 2009;Dupras et al., 2012; Litherland et al., 2008; Hunter et al., 2013). Para arkeolog forensik mampu menghadirkan bukti dalam penuntutan pidana dan kompensasi atas tuntutan yang diajukan oleh pemohon yang meminta bantuannya.

Bukti arkeologis pertama kali digunakan dalam UK Crown Court pada tahun 1988 dan sejak itu telah diakui dalam War Crime Tribunals dan International Criminal Count (ICC) di Den Haag (Cox, 2009). Dalam sejumlah kasus di Inggris, keberhasilan penuntutan tidak akan diperoleh, beberapa pelaku tidak akan dihukum dan keadilan tidak akan tercapai tanpa pengajuan bukti-bukti arkeologisnya (Black, 2000; Hunter, 2002; Blau \& Ubelaker, 2009; Cox, 2009; Hunter, 2009). Di Inggris, para arkeolog forensik adalah anggota departemen atau fakultas arkeologi yang dapat diminta untuk bekerja dengan tim pencari yang dibentuk oleh aparat penegak hukum atau negara atau permintaan lembaga swadaya masyarakat untuk membantu menemukan dan menggali bukti terkubur di tempat kejadian perkara (TKP). Mereka juga memainkan peran penting dalam mengkoordinasikan dan mengintegrasikan dengan para ahli di bidang forensik lainnya, seperti ahli patologi forensik, odontologi forensik, entomologi forensik, botani forensik dan beberapa bidang forensik lain. Disiplin ini menyediakan layanan penting bagi masyarakat dalam mengungkap dan menyelesaikan peristiwa dalam situs-situs kejahatan atau lokasi penemuan korban. Mereka akan memanfaatkan keahlian penelitiannya untuk mengidentifikasi dan menjawab pertanyaanpertanyaan yang unik untuk setiap target yang dibebankan oleh kliennya. Sekedar contoh, beberapa kemungkinan pertanyaan yang bisa diajukan: bagaimana kubur harus digali, apakah ada material asing yang terkubur bersama, apakah identitas dari individu yang terkubur, berapa lama tubuh yang terkubur itu dan bagaimana kita bisa mengetahuinya. Hal ini penting untuk mengumpulkan bukti sebanyak mungkin karena seringkali hanya ada satu kesempatan dan waktu terbatas untuk menggalinya. Oleh karena itu, mereka akan merancang dan memimpin strategi khusus untuk mengoptimalkan bukti yang ada, memberi nasihat tentang metode atau urutan metode yang tepat untuk diterapkan dalam pencarian dan pemulihannya. Dengan cara ini teknik arkeologi dapat digunakan untuk membedakan peristiwa sebelum atau sekitar waktu kematian korban, mendapatkan informasi tentang keadaan penguburan, cara kematian dan alat-alat yang digunakan untuk penguburannya, dan dengan demikian membantu dalam mengidentifikasi pihak ketiga yang bertanggungjawab untuk kejahatannya. Sebelum pengembangan arkeologi forensik, seperti sudah diungkapkan di muka, seringkali para aparat penegak hukum, khususnya kepolisian, untuk menggali situs itu tergesa-gesa dan serampangan demi cepat mengejar 
bukti. Mulai di sinilah arkeologi forensik telah berkembang menjadi suatu disiplin dan diterima secara luas.

Para arkeolog forensik juga berperan untuk misi kemanusiaan, yakni membantu menemukan sisasisa korban (dalam peristiwa pembunuhan politis yang sengaja ditutup kasusnya) walaupun kadangkala di suatu wilayah atau negara tidak ada persyaratan hukum untuk melakukannya, untuk mengembalikannya ke ahli waris atau keluarganya, mulai dari Amerika Latin, Eropa Timur dan Asia (Bernardi \& Fondebrider, 2007; Ferlini, 2007; López \& Umańa, 2007; Skinner, 2007; Flavel \& Barker, 2009; Blau \& Fondebrider, 2010; Mark, 2010; Blau et al., 2011; Rudovica et al., 2011). Pentingnya arkeologi forensik juga terletak pada pencarian dan penyelidikan situs kuburan massal oleh pembantaian politis, genosida dan kejahatan perang (Crossland, 2000; Connor \& Scott, 2001; Haglund et al., 2001; Stover \& Ryan 2001; Skinner et al., 2003; Juhl, 2005; Wright et al., 2005; Juhl \& Olsen, 2006; Bernardi \& Fondebrider, 2007; Ballbé \& Steadman, 2008; Schultz \& Dupras, 2008; Blau \& Ubelaker, 2009; Congram \& Sterenberg, 2009; Flavel \& Barker, 2009; Sterenberg, 2009; Ubelaker, 2009; Blau \& Fondebrider, 2010; Mark, 2010; Cabo et al., 2012; Crossland, 2013).

$$
\text { Beberapa LSM dan }
$$

organisasi internasional mempekerjakan mereka dalam pencarian dan penemuan orangorang hilang atau korban-korban. Organisasi-organisasi ini meliputi International Commission on Missing Persons (ICMP), International Committee of the Red Cross (ICRS) dan beberapa organisasi semacam.
Ahli arkeologi forensik dapat terlibat untuk peran penting dalam proses perdamaian pasca-konflik, masyarakat transisi di mana rekonsiliasi harus menyertakan penyelesaian atas ketidakpastian mengenai nasib beberapa warga "yang sengaja dihilangkan" (Ballbé \& Steadman, 2008; Sterenberg, 2009; Mark, 2010; Rudovica et al., 2011; Kinsella \& Blau, 2013).

Para ahli arkeologi forensik bahkan bersedia untuk memberikan pelatihan dalam metode arkeologi forensik kepada beberapa warga lokal yang kompeten dalam bidang forensik untuk melakukan penyelidikan sendiri. Beberapa kali pelatihan-pelatihan ini, yang dikemas dalam Workshop, telah dilakukan di Indonesia, misalnya Workshop on Disaster Victim Identification pada 24 - 26 November 2007 di Surabaya yang merupakan kerjasama antara Universitas Airlangga, Monash University, the Centre of Human Identification Victorian Institute of Forensic Medicine, Health Sciences Authority Singapore, Ministry of Foreign Affairs Singapore, Departemen Kesehatan Republik Indonesia, Kepolisian Republik Indonesia dan the Australian Agency for International Development; walaupun lebih ditujukan untuk peristiwa-peristiwa korban terorisme. Seorang fasilitatornya adalah ahli antropologi/arkeologi forensik Dr. Soren Blau yang sekarang berkarya di the Centre of Human Identification Victorian Institute of Forensic Medicine, Australia.

Arkeologi forensik semakin berkembang dalam aktivitas Disaster Victim Identification (DVI) (Blau \& Hill, 2009). Para ahli arkeologi forensik membantu mencari dan menyelidiki para korban bencana alam seperti tsunami di Asia 
Tenggara pada tahun 2004 dan badai Katrina yang menghancurkan Louisiana pada tahun 2005 (Blau \& Hill, 2009; Blau \& Ubelaker, 2009), dan bencana oleh manusia dalam kasus-kasus teror, seperti tragedi WTC pada tahun 2001 di Amerika Serikat (Gould, 2004b); serta pertikaian kekuasaan dan genosida yang terjadi di Eropa Timur, Timur Tengah dan Asia Selatan sampai saat ini (Skinner, 2007; Congram \& Sterenberg, 2009; Jankauskas, 2009; Sterenberg, 2009; Mark, 2010). DVI Indonesia dibentuk, berkembang dan bergaung setelah peristiwa teror Bom Bali (Bali Bombing) pada tahun 2002 yang lalu. Peran DVI ini makin penting sejak maraknya kasus terorisme dan kecelakaan transportasi udara dan kapal (Purwanti, 2013).

Sebenarnya beberapa aktivitas yang berkaitan dengan penyelidikan arkeologi forensik telah terekam di Indonesia. Sejauh ini, aktivitas ini masih dilakukan oleh beberapa tenaga profesional nonarkeologis. Di sini bukan berarti hasilnya gagal, namun belum memenuhi kaidah arkeologi forensik yang ideal yang mampu menegaskan bukti-bukti yang rinci dan teguh untuk kelengkapan berkas penyelidikan yang akan diajukan dalam proses hukum sampai ke pengadilan. Penyelidikan arkeologi forensik belum dikenal dalam ranah bukti-bukti penyelidikan forensik kita. Kita juga belum pernah melihat kesaksian ahli arkeologi forensik dalam persidangan di pengadilan kita.

Porsi terbesar aktivitas forensik di Indonesia yang berkaitan dengan korban biologis manusia masih di bawah kewenangan pihak kepolisian kita, biasanya bernaung dalam Pusat Laboratorium Forensik, Pusdokpol (Pusat Kedokteran
Kepolisian) dan RS Polri Bhayangkara. Pihak kepolisian juga sering melibatkan tenaga profesional seperti paramedis di rumah sakit dan fakultas kedokteran yang memiliki instalasi atau bagian forensik (medico-legal), berikutnya DNA forensik, farmasi-kimia forensik, sampai antropologi forensik untuk melengkapi berkas penyelidikannya. Untuk yang terakhir disebut itu pun Indonesia memiliki ahlinya tidak pernah lebih dari jumlah jari-jari di satu tangan kita. Jumlah yang sangat sedikit itu sebenarnya juga adalah mereka yang berkarya dalam antropologi biologis, oleh karena itu, tidaklah heran bahwa mereka tidak bisa berkarya penuh dalam bidang itu karena konsentrasinya terhadang beragam kepentingan profesionalnya (Jacob, 1984, 1999, 2000; Indriati, 1999, 2003, 2004, 2009; Glinka, 2001; Suriyanto, 2008). Seringkali para ahli antropologi biologis itu mengerjakan aspek penyelidikan arkeologi forensiknya.

Beberapa aktivitas ekskavasi berkenaan dengan penyelidikan korban-korban kriminal dengan beragam motif telah dilakukan di beberapa tempat di Indonesia dalam kurun tahun terakhir ini. Sebagian kita masih teringat peristiwaperistiwa berikut ini. Mei 1993 terjadi penculikan dan pembunuhan aktivis buruh Marsinah yang mengguncang dunia peradilan Indonesia. Demi tuntutan keadilan dan hak-hak asasi manusia, maka dilakukan penyelidikan ulang pada tahun 1995, termasuk membongkar makamnya, oleh Tim Penyelidik Khusus Markas Besar Kepolisian RI dengan mengundang beberapa pakar dari Universitas Indonesia, Universitas Gadjah Mada dan Universitas Airlangga. Kita masih teringat peristiwa "korban-korban Ryan", di 
mana pelaku telah membunuh 11 orang, yang satu jasad dimutilasi badannya dan dimasukkan dalam dua tas besar dan dibuang di Jakarta, serta 10 korban lain dan jasad-jasadnya dikubur di belakang rumah orang tuanya di Jombang di antara tahun 2007 - 2008. Penggalian dan penyelidikannya melibatkan ahli antropologi biologis Dr. Toetik Koesbardiati dari Departemen Antropologi Universitar Airlangga. Penggalian pertama 21 Juli 2008 dan kedua 28 Juli 2008 masing-masing mendapati lima individu korban, yang sebagian besar telah kehilangan jaringan lunaknya.

Pada Februari 2011 telah terjadi pembongkaran 24 kuburan bayi di makam-makam kawasan Sedati dan Waru, Sidoarjo; pelaku tidak hanya merusak makamnya tetapi beberapa bukti menunjukkan bahwa sebagian sisa-sisa jasad dan kain kafannya diambil dengan sengaja oleh pelaku dengan tujuan tertentu. Tragedi kubur bayi ini dalam penyelidikan pihak kepolisian, dan melibatkan beberapa ahli dari kedokteran forensik dan medicolegal Fakultas Kedokteran dan Departemen Antropologi Universitar Airlangga. Tidak hanya itu saja, pembunuhan, pemutilasihan, pembuangan dan penguburan enam korban anak-anak dilakukan oleh oknum kelompok remaja di Siak dan Bengkalis pada Agustus 2014.

Untoro \& Atmadja (2012) telah melaporkan pengalamannya melakukan pemeriksaan antropologi forensik untuk mengidentifikasi sisasisa bala tentara Jepang yang gugur pada masa Perang Dunia II di Papua Barat dan Makassar kurun penyelidikan tahun 1999 - 2009. Mereka menyatakan bahwa penyelidikan ini merupakan kerjasama pihak Pemerintah Jepang dan Pemerintah Indonesia, baik dari Departemen Luar Negeri, Departemen Dalam Negeri dan Departemen Kesehatan, maupun Pemerintah Daerah dan Dinas Pariwisata terkait; dan tugas identifikasi dilakukan oleh Untoro dan Atmadja (?) selaku dokter spesialis forensik.

Permintaan penyelidikan ini diajukan Jepang dan perwakilan Lembaga Swadaya Masyarakat di Iwate yang membangun museum untuk peringatan korban Perang Dunia II lewat Kedutaan Besarnya di Jakarta. Lembaga Swadaya Masyarakat itu meneruskan aspirasi keluarga korban bala tentara Jepang itu. Seperti tercatat dalam sejarah, pada tahun 1944, Jepang mengirim sekitar 44.000 tentaranya untuk menduduki Papua Nugini, dan sekitar 13.000 tentaranya di Papua (Papua Barat). Dalam pelayaran menuju tempat pendudukannya, mereka berlabuh untuk menyiapkan logistik di Makassar. Naas, saat itu pula kapal selam mereka mendapat serangan rudal dari bala tentara Amerika Serikat yang dikomando oleh Jenderal McArthur. Kapalnya tenggelam di sekitar Pulau Samalona perairan Makassar. Sebagian kapal Jepang yang telah sampai di perairan dan bala tentara sudah mendarat juga mendapat serangan yang sama; rupanya bala tentara Amerika Serikat telah sampai lebih dulu di sana. Mereka yang selamat bertahan hidup dan bermarkas di beberapa gua, salah satunya di Gua Binsari, Biak Numfor. Sebagian mereka mampu bertahan hidup sampai beberapa tahun kemudian, dan sebagian besarnya meninggal karena beragam penyakit tropis.

Penyelidikan itu membawa misi kemanusiaan yang terdiri dari pengumpulan sisa-sisa rangka 
mereka setelah diidentifikasi dan pengkremasiannya dalam upacara sesuai dengan tata cara mereka. Abunya kemudian diserahkan kepada para ahli warisnya. Kegiatan selanjutnya adalah membersihkan Papua Barat dan Makassar dari sisa-sisa persenjataan dan bom aktif yang berbahaya bagi penduduk setempat.

Untoro dan Atmadja (2012) menuturkan lebih lanjut bahwa penyelidikan itu juga menerapkan metode arkeologi untuk menghasilkan pemeriksaan sisa-sisa rangka manusia yang lebih rinci. Sisa-sisa rangka manusia dari perairan Makassar yang diangkat oleh tim gabungan penyelam TNI Angkatan Laut dan sukarelawan dikumpulkan di Benteng Fort Rotterdam Makassar. Sisa-sisa rangka di Papua Barat dikumpulkan dari berbagai pulau yang tersebar di sana oleh pihak Jepang dan penduduk lokal yang diminta membantu. Penduduk lokal ini sebelumnya telah mendapatkan arahan dan pelatihan. Selanjutnya, sisa-sisa rangka tersebut disimpan dalam lemari-lemari khusus di lokasi sekitar Gua Binsani, Biak Numfor.

Usaha pengumpulan sisasisa rangka para prajurit Jepang ini dikerjakan selama beberapa bulan. Mereka melakukan pendokumentasian visual dan catatan terlebih dulu sebelum melakukan penggalian di lokasi yang diduga merupakan kuburan massal bala tentara Jepang itu. Pendokumentasiannya juga meliputi semua artefak yang ditemukan di sekitarnya, yang diduga sebagai barang-barang milik mereka. Penggalian dilakukan sampai ditemukan sisa-sisa tulang. Tulang yang telah terekspos keseluruhan akan diangkat dan dikumpulkan, selanjutnya sisa-sisa rangka itu dimasukkan ke kantong-kantong untuk masing-masing yang diduga sebagai satu individu. Artefakartefak yang ditemukan dalam penggalian itu dikumpulkan, sebagian dibawa ke Jepang, dan sebagian lagi menjadi koleksi museum yang didirikan di sekitar Gua Binsari.

Pemeriksaan dan identifikasi rangka-rangkanya dilakukan oleh tim Kedokteran Forensik Universitas Indonesia. Aktivitas ini terdiri dari memeriksa dan mengidentifikasi profil biologisnya, memperkirakan periode postmortemnya, dan menyediakan data yang berhubungan dengan kematiannya, termasuk bukti-bukti adanya trauma yang terjadi selama periode kematiannya. Keseluruhan tulang, baik utuh maupun fragmentaris, yang dikumpulkan sekitar 25.000 tulang; sejauh ini, yang telah berhasil diidentifikasi 605 individu.

Peristiwa lain yang bisa disebut sebagai ranah arkeologi forensik yang berkaitan dengan temuan paleoantropologis Indonesia, yakni upaya pemulangan fosil Homo erectus Sambungmacan 3 (Sm 3) dari sebuah toko barang antik (the natural history shop) terkemuka Maxilla \& Mandible Ltd. di New York, Amerika Serikat (Broadfield et al., 2001; Delson et al., 2001; Laitman \& Tattersall, 2001; Márques et al., 2001). Berita tentang hal ini telah dimuat di halaman muka surat kabar ternama New York Times dan beberapa media di Amerika Serikat pada 7 September 1999, termasuk kasak-kusuk harga di internal pedagang-pedagang barang antik, khususnya yang selundupan, yang ditawarkan sekitar $\$ 500.000,00$. Berkat perjuangan dan diplomasi Prof. Dr. T. Jacob, M.S., M.D., D.Sc., fosil ini telah diserahkan kembali ke Indonesia, dan tersimpan di 
Laboratorium Bioantropologi dan Paleoantropologi Fakultas Kedokteran Universitas Gadjah Mada tanpa mengeluarkan ganti rugi sama sekali. Prof. Dr. T. Jacob, M.S., M.D., D.Sc mengungkapkan bahwa pengembalian ini merupakan upaya atas nama ilmu pengetahuan dan warisan nasional. Fosil tersebut merupakan material ilmu pengetahuan yang sangat berharga bagi sejarah pertumbuhan dan perkembangan peradaban umat manusia (Suriyanto, 2012).

Penerimaan kembali fosil ini disaksikan oleh Drs. Hari Untoro Drajat, M.A. dari Direktorat Jenderal Kebudayaan Departemen Pendidikan dan Kebudayaan RI dan Atase Kebudayaan RI di sana Dr. Yahya Muhaimin, Prof. Eric Delson dari City University New York, dan beberapa kolega ilmuwan di sana, antara lain dari American Museum of Natural History. Sebagai bentuk persahabatan di antara para ilmuwan paleoantropologi Amerika
Serikat dan Indonesia, beliau bersama para kolega itu telah meneliti dan mempublikasikan fosil ini dalam serial khusus di jurnal terkemuka The Anatomical Record (2001). Artikel-artikel di jurnal tersebut menegaskan bahwa fosil ini sangat penting karena morfologinya lebih maju secara evolusioner dari Homo erectus erectus, namun belum mencapai morfologi Homo erectus soloensis (Broadfield et al., 2001; Delson et al., 2001; Laitman \& Tattersall, 2001; Márques et al., 2001).

Kesediaan Henry Galiano untuk mengembalikan fosil yang telah dikuasai dan diumumkan keberadaanya sejak 29 Agustus 1999 menunjukkan keberhasilan dan kesungguhan diplomasi dari pihak Indonesia untuk meminta kembali benda yang sangat berharga bagi perkembangan sejarah dan budaya Indonesia (Boedhihartono, 1998; Suriyanto, 2012).

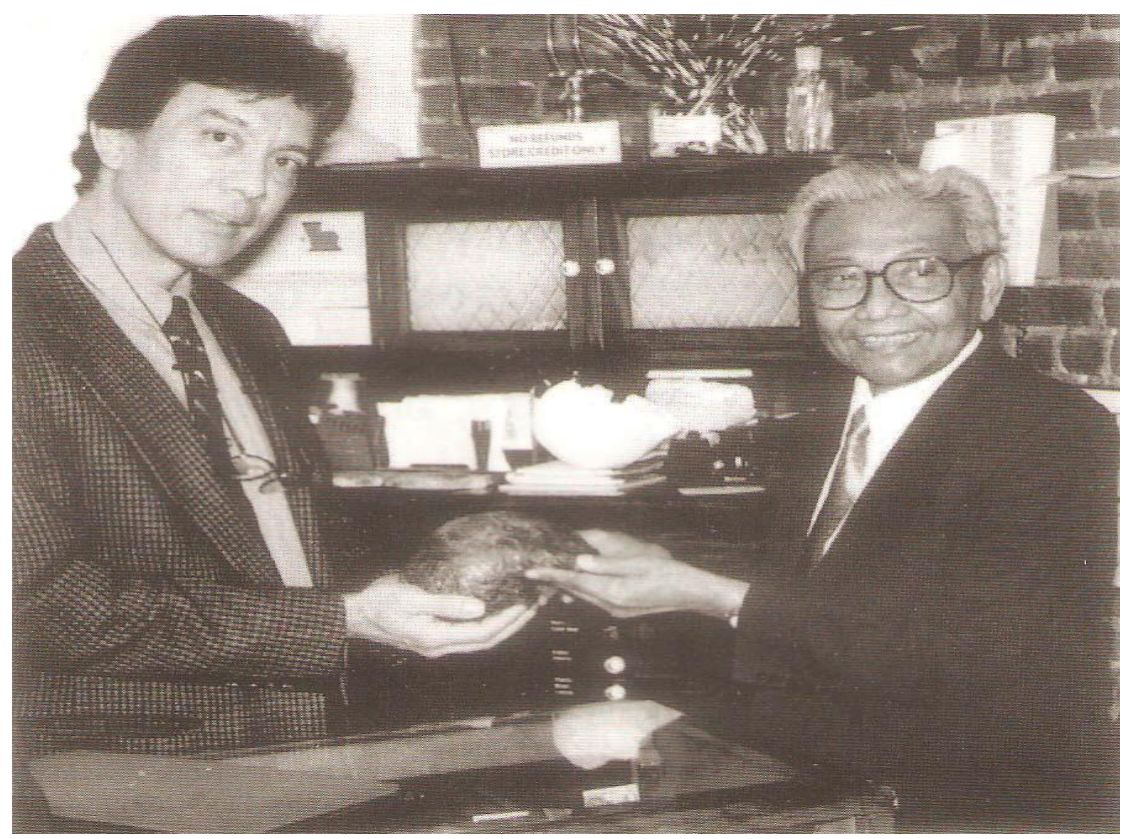

Gambar 1. Henry Galiano menyerahkan kembali fosil Homo erectus (Sambungmacan 3, Sm 3) dari situs Sambungmacan, Sragen, kepada Prof. T. Jacob di New York (koleksi dan sumber foto: Eric Delson untuk Laitman \& Tattersall, 2001) 


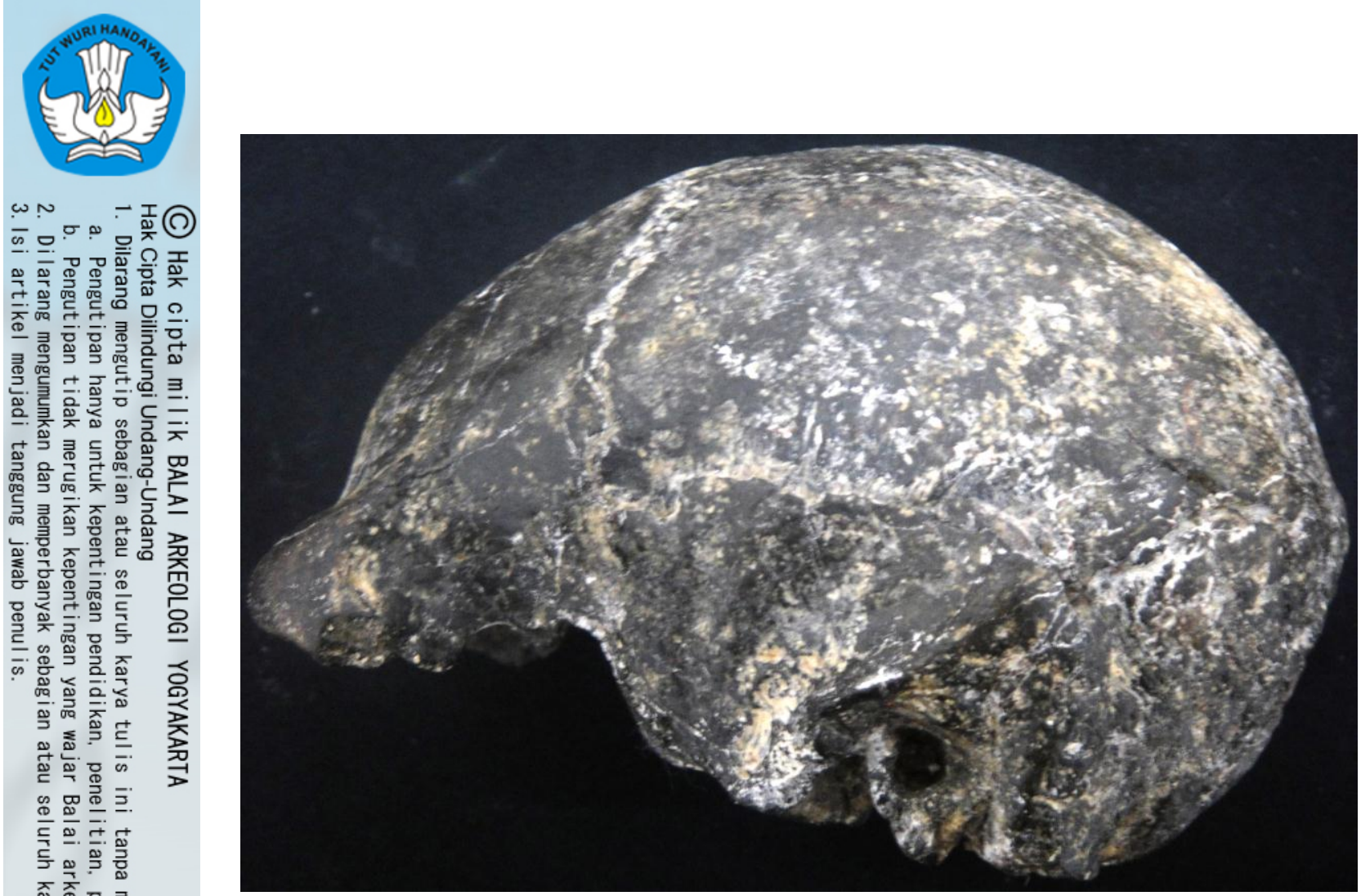

Gambar 2. Fosil Homo erectus (Sambungmacan 3, Sm 3) dari situs Sambungmacan, Sragen (lateral kiri, koleksi foto: Rusyad Adi Suriyanto)

\section{HARAPAN DAN UPAYA PENGEMBANGAN ARKEOLOGI FORENSIK INDONESIA}

Seperti telah diungkapkan di muka, Indonesia yang dihuni oleh banyak populasi dengan variasi biologisnya yang nyata dari masa Pleistosen sampai sekarang hanya mempunyai sangat sedikit ahli antropologi biologis dan ahli paleoantropologi. Jumlah tersebut tidak seimbang dengan jumlah penelitian dan pengembangan biologi manusia yang bermanfaat untuk kedokteran, kehidupan sosial, politik, kebudayaan, pembangunan sumber daya manusia, keanekaragaman hayati, perdamaian dan kesejahteraan masyarakat (Glinka, 2001; Suriyanto, 2008).

Keadaan tersebut di atas menjadi semakin memprihatinkan ketika mengetahui jumlah ahli antropologi forensik Indonesia (Jacob, 1984, 1999, 2000; Indriati, 1999, 2003, 2004, 2009; Glinka, 2001; Suriyanto, 2008). Permasalahan biologi manusia dan aspek hukumnya semakin kompleks; bukan saja berhadapan dengan konteks yang baru saja dan berlangsung di masa kini, namun permasalahan itu kadangkala harus dirunut jauh ke belakang. Sebagai contoh, tuntutan atas penemuan dan pengembalian korban-korban perang, genosida, penghilangan orang dalam konflik politik dan perbudakan lintas negara di masa lalu, terutama setelah Perang Dunia II. Para praktisi antropologi forensik yang ada di Universitas Gadjah Mada dan Universitas Airlangga tidak dapat sepenuhnya bekerja dalam keahlian itu. Mereka memiliki kewajiban lain seperti mengajar, meneliti dan memberikan pengabdian kepada masyarakat 
dalam bidang antropologi biologis. Mereka akan bekerja dalam keahlian itu jika diminta oleh lembaga terkait, baik kedokteran forensik, kepolisian dan DVI, untuk membantu menemukan, memeriksa dan mengidentifikasi korban-korban atau jenazah-jenazah oleh beragam bencana. Kadangkala mereka juga menjadi tenaga ahli untuk membantu penelitian arkeologis yang berkaitan dengan temuan-temuan osteologis.

Berdasaran pemaparan di atas, diketahui bahwa banyak penyelidikan arkeologi forensik telah dikerjakan di Indonesia, namun yang menjadi permasalahan apakah kita memiliki ahli arkeologi forensik yang memadai jumlah maupun keahliannya? Jawaban atas pertanyaan itu adalah kita belum memilikinya. Sebagian penyelidikan arkeologi forensik itu masih dilakukan oleh ahli antropologi biologis, khususnya mereka yang mendalami antropologi mati (osteologi) dengan salah satu disiplinnya adalah antropologi forensik. Hanya ada tiga orang ahli antropologi forensik yang aktif sekarang ini di Indonesia. Mereka tidak hanya bertindak sebagai ahli antropologi forensik namun juga mengerjakan pekerjaan yang seharusnya dilakukan oleh ahli arkeologi forensik. Penyelidikan demikian tidak akan pernah rinci dan tuntas karena seringkali begitu banyak rangka korban yang perlu diidentifikasi dalam waktu yang terbatas. Dalam situasi seperti ini, maka keahlian utama dari penyelidik, antropologi forensik, yang lebih dominan menuntun aktivitas penyelidikan dan pelaporannya.

Pekerjaan lain yang dilakukan dalam kaitannya dengan penyelidikan arkeologi forensik adalah melengkapi berkas penyelidikan sesegera mungkin kepada aparat kepolisian di mana para tersangka dan saksi masih memungkinkan untuk dikorek keterangannya lebih lanjut. Mereka memeriksa dan mengidentifikasi profil biologisnya, memperkirakan periode postmortemnya, dan menyediakan data yang berhubungan dengan kematiannya, termasuk bukti-bukti adanya trauma yang terjadi selama periode kematiannya. Pemeriksaan itu tidak akan sedetail jika para korban itu berupa rangka-rangka yang telah tertimbun tanah bertahun-tahun.

Perlu untuk diperhatikan bahwa pendidikan formal untuk jenjang sarjana dan pascasarjana antropologi forensik di Indonesia belum ada. Namun, pendidikan ini telah menjadi salah satu minat atau disiplin dalam antropologi biologis, misalnya beberapa mahasiswa Departemen Antropologi Universitas Airlangga telah mengerjakan skripsinya bertema minat tersebut. Mata kuliah Antropologi Forensik juga telah diberikan bagi mahasiswa pendidikan Magister Forensik. Di Universitas Gadjah Mada juga telah diberikan kepada jenjang Pendidikan Dokter Fakultas Kedokteran; yang sekarang melebur ke dalam Block 4.2. Health System and Disaster. Perkuliahan dan praktikum mata kuliah antropologi forensik diberikan sebagai Forensic Anthropology in DVI. Untuk jenjang magisternya diberikan kepada minat utama Antropologi Kedokteran. Dalam aktivitas itu, juga diperkenalkan arkeologi forensik. Ini tidak mengherankan karena sebenarnya antropologi dan arkeologi forensik selalu beriringan, saling melengkapi dan membutuhkan; bahkan banyak kalangan menyebut arkeologi forensik itu adalah bagian dari antropologi forensik (Lovis, 1992; 
Scott \& Connor, 2001; Blau \& Ubelaker, 2009; Cox, 2009; Jankauskas, 2009; Ubelaker, 2009; Byers, 2011; Gowland \& Thompson, 2013). Antropologi forensik di Indonesia makin menunjukkan perkembangan optimis walaupun, seperti telah disebut di muka, masih memerlukan perhatian dan pengembangannya (Indriati, 2009).

Situasi arkeologi Indonesia sekarang berbeda dengan sebelumnya. Beberapa paradigma arkeologi masa kini makin memperkaya khazanah arkeologi Indonesia. Paradigma ini makin memperkaya metodologi penelitian arkeologi Indonesia, diantaranya adalah metode yang dipakai dalam bidang biologi dan ilmu-ilmu eksakta. Lambat namun pasti, beberapa disiplin ilmu perbatasan terus berkembang, antara lain: bioarkeologi, zooarkeologi, osteoarkeologi, dan arkeologi nutrisi. Momentum ini merupakan kesempatan baik untuk makin memperkenalkan dan mengembangkan arkeologi forensik.

Keadaan seperti ini juga pernah dialami oleh beberapa negara, misalnya Australia. Arkeologi forensik merupakan kajian dan minat baru yang makin berkembang di Australia masa kini, dan terus diupayakan makin luas dalam kurikulum perkuliahan arkeologi di universitas-universitas Australia pada abad ini (Blau 2004; Pate, 2005). Ahli antropologi biologis dan paleoantropologi Prof. Maciej Henneberg dari Australia pernah memberikan kursus School of Anthropological and Forensic Anatomy di Departemen Anatomi dan Histologi Fakultas Kedokteran Universitas Airlangga pada Desember 2011. Salah satu sesi dari kursus tersebut membicarakan tentang arkeologi forensik, identifikasi rangka, paleopathologi dan peranan ahli antropologi biologis (Kalanjati, 2012).

Dorongan

untuk

mengembangkan arkeologi forensik di Indonesia dapat mengambil pengalaman dari sejarah munculnya disiplin ini di beberapa negara seperti Amerika Utara, Inggris dan beberapa negara Eropa. Arkeologi forensik telah berkembang selama 20 tahun terakhir di negara-negara tersebut dan sekarang menjadi suatu disiplin yang mantap, yang memberikan sumbangsih penting untuk penyelidikan-penyelidikan kriminal dan bukti-bukti penyelidikannya mampu mempengaruhi argumentasiargumentasi hukumnya di pengadilan serta membantu dalam penyelidikan bencana massal (Connor \& Scott, 2001; Haglund, 2001; Gould, 2004a; Gould, 2004b; Hunter \& Cox, 2005b; Hunter \& Cox, 2005c; Wright et al., 2005; Ellis, 2007; Ferlini, 2007; López \& Umańa, 2007; Cox et al., 2008; Blau \& Hill, 2009; Blau \& Ubelaker, 2009; Hochrein, 2009; Hunter, 2009; Steadman et al., 2009).

Indonesia adalah negeri yang rawan bencana. Hal ini dipengaruhi oleh letak negeri kita di antara lempeng-lempeng geologis Asia dan Australia, kawasan jalur ring of fire Pasifik yang kawasannya banyak memiliki gunung vulkanik, kawasan perubahan musim hujan dan kemarau, angin dan gelombang di antara Asia dan Australia, negeri yang terdiri ribuan pulau dengan transportasi utama kapal dan pesawat. Posisi Indonesia sebagaimana disebutkan di atas memiliki potensi terjadinya bencana baik yang disebabkan oleh alam maupun manusia.

Penyelidikan dengan menggunakan arkeologi forensik 
juga dilakukan pada periwtiwaperistiwa kemanusiaan di masa lalu. Penegakkan hak-hak asasi manusia menjadi isu, baik teoretis maupun praktis, yang terus makin berkumandang seiring seruan demokratisasi di beberapa negara. Penegakkan ini tidak melulu sebagai urusan nasional, namun seringkali menjadi urusan internasional. Perlawanan dan protes atas buruknya upaya-upaya itu disuarakan para aktivis dalam negeri suatu negara; seringkali pula gerakan itu diilhami dan mendapat sokongan oleh gerakan-gerakan dari luar negaranya. Beberapa di antara mereka menyuarakan tuntutan pengembalian orang-orang yang dihilangkan dengan paksa oleh beragam alasan, baik oleh oknum kelompok atau aparat negara, di mana saat itu dianggap membahayakan kelompoknya atau negara. Tuntutan ini juga berlaku terhadap peristiwa-peristiwa kemanusian seperti genosida, pembunuhan politik, kejahatan perang dan pelanggaran hak asasi manusia (Crossland, 2000; Connor \& Scott, 2001; Haglund et al., 2001; Stover \& Ryan 2001; Skinner et al., 2003; Hunter \& Cox, 2005b; Juhl, 2005; Wright et al., 2005; Juhl \& Olsen, 2006; Bernardi \& Fondebrider, 2007; Skinner, 2007; Ballbé \& Steadman, 2008; Schultz \& Dupras, 2008; Steel, 2008; Blau \& Ubelaker, 2009; Congram \& Sterenberg, 2009; Flavel \& Barker, 2009; Sterenberg, 2009; Ubelaker, 2009; Wright \& Hanson, 2009; Blau \& Fondebrider, 2010; Mark, 2010; Blau et al., 2011; Cabo et al., 2012; Tuller, 2012; Crossland, 2013; Kinsella \& Blau, 2013).

Dengan mempertimbangkan peran arkeologi forensik dalam penyelidikan-penyelidikan berkaitan dengan peristiwa-peristiwa forensik, maka perlu diupayakan untuk menawarkan minat khusus arkeologi forensik kepada para mahasiswa arkeologi Indonesia. Para mahasiswa ini diharapkan dapat berpartisipasi dalam membantu aktivitas-aktivitas forensik setelah menyelesaikan studinya. Selama ini arkeologi forensik masih merupakan salah satu topik dalam matakuliah Paleoantropologi dan Bioarkeologi untuk mahasiswa jenjang sarjana di Departemen Arkeologi Universitas Gadjah Mada.

Apabila jumlah ahli arkeologi forensik telah mencukupi, maka kita tidak perlu lagi bergantung kepada pihak asing pada saat melakukan penyelidikan yang berkaitan dengan arkeologi forensik. Lulusan arkeologi Indonesia yang telah mendalami arkeologi forensik dapat menjadi tenaga profesional yang sebenarnya makin dibutuhkan oleh negara ini seturut makin meningkatnya pengakuan atas hak-hak asasi manusia dan harapan atas kejelasan nasib para korban yang sengaja dihilangkan oleh oknum-oknum yang tidak bertanggungjawab, dan peristiwa-peristiwa bencana yang dapat memindahkan dan mengubur para korbannya. Para ahli arkeologi forensik ini juga dapat bergabung dan membantu DVI Indonesia baik untuk penanganan para korban beragam bencana dari masa kini sampai upaya pencarian para korban pertikaian atau konflik politik di masa lalu. Mereka juga dapat memenuhi permintaan bantuan tenaga profesional oleh pihak internasional, misalnya untuk melakukan pencarian dan identifikasi para korban peristiwa penembakan pesawat penumpang komersial maskapai Malaysia Airline di kawasan Ukraina pada 17 Juli 2014 lalu yang menewaskan 295 penumpang dan awaknya. 
Di masa yang akan datang, pendirian DVI Indonesia akan terus diupayakan di wilayah-wilayah negara kita, agar penanganan para korban bencana makin cepat dan tepat (Kepolisian Republik Indonesia, 2006). Meskipun antropologi dan arkeologi forensik belum diakui secara resmi dalam proses tahapan DVI (yakni, tidak adanya ruang yang diberikan untuk rekaman informasinya pada formulir DVI untuk blanko merah muda postmortem), disiplin-disiplin itu merupakan bagian penting dari pendekatan multidisiplin untuk penyelidikan bencana massal baik dari fase pemulihan sampai analisisnya.

Sampai 20 tahun terakhir, komunitas medico-legal telah mulai merangkul dan membutuhkan sumbangan disiplin-disiplin itu dalam setiap kerja penyelidikan dan identifikasi korban. Dalam konteks pedoman untuk proses DVI yang terdiri atas lima tahapan, arkeologi forensik lebih berperan daripada antropologi forensik, karena tidak saja berkonsentrasi utama pada tahap kedua, yakni phase 2: involves the collection of post-mortem data from deceased individuals, namun juga secara proporsional berperan dalam phase 1: involves the investigation of the scene of the disaster. Tahapan ketiga sampai kelima adalah phase 3: involves the collection of ante-mortem information from the community in relation to persons possibly involved in the disaster, phase 4: involves the matching of the ante-mortem and post-mortem information and presentation of the findings to constituted reconciliation Board, dan phase 5: involves the process of debriefing all personnel involved in the DVI (Kepolisian Republik Indonesia, 2006; Blau \& Hill, 2009).

\section{PENUTUP}

Penerapan prinsip-prinsip dan teknik-teknik arkeologis telah menjadi keharusan ketika berhadapan dengan pemulihan temuan-temuan terkubur dan sisasisa biologis manusia. Penerapan metode dan teori arkeologis serta partisipasi aktual ahli arkeologi terbukti diperlukan untuk membantu penyelidikan kasus-kasus medicolegal. Peningkatan kebutuhan akan ahli arkeologi forensik ini sesuai dengan makin meningkatnya pengakuan atas hak-hak asasi manusia dan harapan atas kejelasan nasib para korban yang sengaja dihilangkan oleh oknum-oknum yang tidak bertanggungjawab dan peristiwa-peristiwa bencana yang dapat memindahkan dan mengubur para korbannya. Keahlian ini juga penting untuk membantu mengungkap temuan sisa-sisa manusia purba dan kuno milik negara ini yang diperjual-belikan dan diselundupkan ke manca negara untuk mencari keuntungan finansial belaka.

Sehubungan dengan penting dan mendesaknya kebutuhan terhadap ahli arkeologi forensik, maka perlu upaya untuk menjadikan arkeologi forensik sebagai salah satu minat khusus pada Departemen Arkeologi. Mahasiswa yang mengambil minat khusus arkeologi forensik diharapkan dapat berpartisipasi dalam membantu aktivitas-aktivitas forensik setelah menyelesaikan pendidikannya. Mereka dapat juga menjadi tenaga profesional dalam arkeologi forensik yang keahliannya makin dibutuhkan oleh negeri ini. 


\section{UCAPAN TERIMA KASIH}

Terima kasih kepada Ikatan

Ahli Arkeologi Indonesia (IAAI) Komisariat Daerah DI Yogyakarta dan Jawa Tengah yang telah memberikan kesempatan untuk mempresentasikan makalah ini dalam Diskusi IImiah Arkeologi "Integrasi Pengembangan Arkeologi Indonesia" pada 25 Juni 2014, di Museum Benteng Vredeburg, Yogyakarta. 


\section{DAFTAR PUSTAKA}

Ballbé, E.G. \& Steadman, D.W. 2008. "The Political, Social and Scientific Contexts of Archaeological Investigations of Mass Graves in Spain". Archaeologies 4: 429 - 444.

Barone, P.M. 2012. "Archaeology, Geophysics and Forensic: United We Stand, Divided We Fall". Geophysics 1:131 - 137.

Bernardi, P. \& Fondebrider, L. 2007. "Forensic Archaeology and the Scientific Documentation of Human Rights Violations: An Argentinian Example from the Early 1980s", dalam R. Ferlini (ed.) Forensic Archaeology and Human Rights Violations. Springfield: Charles C Thomas. HIm. 205- 232.

Black, S. 2000. "Forensic Osteology in the United Kingdom", dalam M. Cox \& S. Mays (eds.) Human Osteology in Archaeology and Forensic Science. London: Greenwich Medical Media. HIm. 491 - 503.

Blau, S. 2004. "Forensic Archaeology in Australia: Current Situations, Future Possibilities". Australian Archaeology 58:11 - 14.

Blau, S. \& Fondebrider, L. 2010. "Dying for Independence: Proactive Investigations into the 12 November 1991 Santa Cruz Massacre, Timor Leste". The International Journal of Human Rights 15: 1249 - 1274.

Blau, S., Fondebrider, L. \& Saldanha, G. 2011. "Working with Families of the Missing: A Case Study from East Timor", dalam K. Lauritsch \& F. Kernjak (eds.) We Need the Truth: Enforced Disappearances in Asia. Guatemala: ECAP. HIm. $136-144$.

Blau, S. \& Hill, T. 2009. "Disaster Victim Identification: A Review". Minerva Medico-legale 129: 35 - 36.

Blau, S. \& Ubelaker, D.H. 2009. "Forensic Anthropology and Archaeology: Introduction to A Broader View", dalam S. Blau \& D.H. Ubelaker (eds.) Handbook of Forensic Archaeology and Anthropology. Walnut Creek: Left Coast Press. HIm. $21-26$.

Boedhihartono 1998. "A New Homo erectus Finding". Jurnal Antropologi Indonesia 54: 121 - 125.

Broadfield, D.C., Holloway, R.L., Mowbray, K., Silvers, A., Yuan, M.S., Márquez, S. 2001. "Endocast of Sambungmacan 3 (Sm 3): A New Homo erectus from Indonesia". The Anatomical Record 262: 369 - 379.

Burns, K.R. 1999. Forensic Anthropology Training Manual. Upper Saddle River: Prentice-Hall, Inc.

Byers, S.N. 2011. Introduction to Forensic Anthropology, $4^{\text {th }}$ ed. Upper Saddle River: Pearson Education, Inc. 
Cabo, L.L., Dirkmaat, D.C., Adovasio, J.M. \& Rozas, V.C. 2012. Archaeology, Mass Graves, and Resolving Commingling Issues Through Spatial Analysis", dalam D.C. Dirkmaat (ed.) A Companion to Forensic Anthropology. Chichester: Blackwell Publishing Ltd. HIm. 175 - 195.

Cheetham, P.N. \& Hanson, I. 2009. "Excavation and Recovery in Forensic Archaeological Investigations", dalam S. Blau \& D.H. Ubelaker (eds.) Handbook of Forensic Archaeology and Anthropology. Walnut Creek: Left Coast Press. HIm. 141 - 149.

Congram, D. \& Sterenberg, J. 2009. Grave Challenges in Iraq", dalam S. Blau \& D.H. Ubelaker (eds.) Handbook of Forensic Archaeology and Anthropology. Walnut Creek: Left Coast Press. HIm. 441 - 453.

Connor, M. \& Scott, D.D. 2001. "Paradigms and Perpetrators". Historical Archaeology 35: $1-6$.

Crossland, Z. 2000. "Buried Lives: Forensic Archaeology and the Disappeared in Argentina". Archaeological Dialogues 72: 146 - 159.

Cox, M., Flavel, A., Hanson, I., Laver, J. \& Wessling, R. 2008. The Scientific Investigation of Mass Graves. Cambridge: Cambridge University Press.

Cox, M. 2009. "Forensic Anthropology and Archaeology: Past and Present - A United Kingdom Perspective", dalam S. Blau \& D.H. Ubelaker (eds.) Handbook of Forensic Archaeology and Anthropology. Walnut Creek: Left Coast Press. HIm. $29-41$.

Crist, T. A. J. 2001. "Bad to the Bone? Historical Archaeologist in the Practise of Forensic Science". Historical Archaeology 35: 39 - 56.

Crossland, Z. 2013. "Evidential Regimes of Forensic Archaeology. Annual Review of Anthropology 42: 121 - 137.

Davenport, A \& Harrison, K. 2011. "Swinging the Blue Lamp: the Forensic Archaeology of Contemporary Child and Animal Burial in the UK". Mortality 16: $176-190$.

Delson, E., Harvati, K., Reddy, D., Marcus, L.F., Mowbray, K., Sawyer, G.J., Jacob, T. \& Márquez, S. 2001. "The Sambungmacan 3 Homo erectus Calvaria: A Comparative Morphometric and Morphological Analysis". The Anatomical Record 262: 380 - 397.

Dirkmaat, D.C. \& Adovasio, J.M. 1997. "The Role of Archaeology in the Recovery and linterpretation of Human Remains from An Outdoor Forensic Setting", dalam W.W. Haglund \& M.M. Sorg (eds.) Forensic Taphonomy: the Postmortem Fate of Human Remains. Boca Raton: CRC Press. HIm. 39 - 64. 
Dirkmaat, D.C., Cabo, L.L., Ousley, S.D. \& Symes, S.A. 2008. "New Perspectives in Forensic Anthropology". American Journal of Physical Anthropology 137 (S47): $33-52$.

Duhig, C. 2003. "Non-forensic Remains: the Use of Forensic Archaeology, Anthropology and Burial Taphonomy". Science \& Justice, 43: $211-214$.

Dupras, T.L., Schultz, J.J., Wheeler, S.M. \& Williams, L.J. 2012. Forensic Recovery of Human Remains: Archaeological Approaches, $2^{\text {nd }}$ ed. Boca Raton: CRC Press.

Ellis, P. 2007. "Archaeology and Forensic Pathologist", dalam R. Ferlini (ed.) Forensic Archaeology and Human Rights Violations. Springfield: Charles C Thomas. HIm. $101-121$.

Ferlini, R. 2007. Human Rights Violations, Past and Present: Concequences and Interventions", dalam R. Ferlini (ed.) Forensic Archaeology and Human Rights Violations. Springfield: Charles C Thomas. HIm. 3-23.

Flavel, A. \& Barker, C. 2009. "Forensic Anthropology and Archaeology in Guatemala", dalam S. Blau \& D.H. Ubelaker (eds.) Handbook of Forensic Archaeology and Anthropology. Walnut Creek: Left Coast Press. HIm. 426 -440 .

Galloway, A. \& Simmons, T. 1997. "Education in Forensic Anthropology: Appraisal and Outlook". Journal of Forensic Science 42: 796 - 801.

Glinka, J. 2001. "Morphological Variation of Contemporary Indonesians, dalam E. Indriati (ed.) A Scientific Life: Papers in Honor of Prof. Dr. T. Jacob Proceeding of Conference on Man: Past, Present and Future. Yogyakarta: Bigraf Publishing. HIm. 91 - 104.

Gould, R.A. 2004a. "Disaster Archaeology at the West Warwick Rhode Island Night-club Fire Scene". Archaeological Record 4: 6 - 11.

2004b. "WTC Archaeology: What We Saw, What We Learned, and What We Did About It". Archaeological Record 4: 11 - 17.

Gowland, R. \& Thompson, T. 2013. Human Identity and Identification. Cambridge: Cambridge University Press.

Haglund, W.D. 2001. "Archaeology and Forensic Death Investigations". Historical Archaeology 35: 26 - 34.

Haglund, W.D., Connor, M. \& Scott, D.D. 2001. "The Archaeology of Contemporary Mass Grave". Historical Archaeology 35: 57 - 69.

Hochrein, M. 2002. "Polar Coordinate Mapping and Forensic Archaeology Within Confined Spaces". Journal of Forensic Identification 52: 733 - 749. 
2009. "Domestic Homicide Investigations: United States", dalam S. Blau \& D.H. Ubelaker (eds.) Handbook of Forensic Archaeology and Anthropology. Walnut Creek: Left Coast Press. HIm. 351 - 362.

Holland, T.D. \& Connell, S.V. 2009. "The Search for and Detection of Human Remains, dalam S. Blau \& D.H. Ubelaker (eds.) Handbook of Forensic Archaeology and Anthropology. Walnut Creek: Left Coast Press. HIm. 129 -140 .

Hoshower, L.M. 1998. "Forensic Archaeology and the Need for Flexible Excavation Strategies: A Case Study". Journal of Forensic Science 43: 53 -56 .

Hunter, J.R. 2002. "A Background to Forensic Archaeology, dalam J. Hunter, C. Roberts \& A. Martin (eds.) Studies in Crime: An Introduction to Forensic Archaeology. New York: Routledge. HIm. 7 - 23.

Hunter, J. 2009. "Domestic Homicide Investigations in the United Kingdom", dalam S. Blau \& D.H. Ubelaker (eds.) Handbook of Forensic Archaeology and Anthropology. Walnut Creek: Left Coast Press. HIm. $363-373$.

Hunter, J. \& Cox, M. 2005a. "Introduction", dalam J. Hunter \& M. Cox (eds.) Forensic Archaeology: Advances in Theory and Practice. New York: Routledge. HIm. 1 - 26.

2005b. Search and Location: Case Studies 1 - 13", dalam J. Hunter \& M. Cox (eds.) Forensic Archaeology: Advances in Theory and Practice. New York: Routledge. HIm. $27-61$.

2005c. "The Recovery of Forensic Evidence from Individual Graves: Case Studies 14 - 29", dalam J. Hunter \& M. Cox (eds.) Forensic Archaeology: Advances in Theory and Practice. New York: Routledge. HIm. 96 - 136.

Hunter, J., Simpson, B. \& Colls, C.S. 2013. Forensic Approaches to Buried Remains. Chichester: Wiley Blackwell.

Indriati, E. 1999. "Peran Antropologi Forensik Pada Identifikasi", dalam R. Soegandhi (ed.) Aplikasi IImu Kedokteran Forensik untuk Identifikasi. Yogjakarta: Fakultas Kedokteran Universitas Gadjah Mada. HIm. 77 - 89.

2003. "Mati: Tinjauan Klinis dan Antropologi Forensik". Berkala IImu Kedokteran 35: $231-239$.

2004. Antropologi Forensik: Identifikasi Rangka Manusia, Aplikasi Antropologi Biologis dalam Konteks Hukum. Yogyakarta: Gadjah Mada University Press.

2009. "Historical Perspectives on Forensic Anthropology in Indonesia", dalam S. Blau \& D.H. Ubelaker (eds.) Handbook of Forensic 
Archaeology and Anthropology. Walnut Creek: Left Coast Press. HIm. 115 $-125$.

Jacob, T. 1984. "Bioanthropologi Kematian", dalam I. Nuhriawangsa (ed.) Kelahiran, Kehidupan dan Kematian. Yogyakarta: Fakultas Kedokteran Universitas Gadjah Mada. HIm. 97 - 105.

1999. "Identifikasi Manusia", dalam R. Soegandhi (ed.) Aplikasi IImu Kedokteran Forensik untuk Identifikasi. Yogjakarta: Fakultas Kedokteran Universitas Gadjah Mada. HIm. 1 - 11.

2000. "Antropologi Forensik", dalam E. Indriati (ed.) Buku Bacaan Antropologi Biologis. Jakarta: Direktorat Pendidikan Tinggi Departemen Pendidikan Nasional RI. HIm. 137 - 148.

Jankauskas, R. 2009. "Forensic Anthropology and Mortuary Archaeology in Lithuania". Anthropologischer Anzeiger 67: 391 - 405.

Jessee, E. \& Skinner, M. 2005. "A Typology of Mass Grave and Mass GraveRelated Sites". Forensic Science International 152: 55 - 59.

Juhl, K. 2005. The Contribution by (Forensic) Archaeologists to Human Rights Investigations of Mass Graves. Stavanger: Arkeologisk museum i Stavanger.

Juhl, K. \& Olsen, O.E. 2006. "Societal Safety, Archaeology and the Investigation of Contemporary Mass Graves. Journal of Genocide Research 8: 411 435.

Kalanjati, V.P. 2012. "Program Pendidikan Anatomi Antropologi dan Forensik di Fakultas Kedokteran Universitas Airlangga Surabaya, Indonesia", dalam M.D. Artaria \& F.N. Ariningsih (eds.) Bunga Rampai Antropologi Ragawi: 80 Tahun Prof. Dr. Habil. Jozef Glinka SVD. Surabaya: Fakultas IImu Sosial dan IImu Politik Universitas Airlangga. HIm. 113 - I18.

Kepolisian Republik Indonesia 2006. Disaster Victim Identification: Pedoman Penatalaksanaan Identifikasi Korban Mati pada Bencana Massal. Jakarta: Departemen Kesehatan RI dan Kepolisian Negara RI.

Kinsella, N \& Blau, S 2013. "Searching for Conflict-related Missing Persons in Timor-Leste: Technical, Political and Cultural Considerations". Stability 2: $1-14$.

Larsen, C.S. 2000. Bioarchaeology: Interpreting Behavior from the Human Skeleton. Cambridge: Cambridge University Press.

Laitman, J.T. \& Tattersall, I. 2001. "Homo erectus newyorkensis: An Indonesian Fossil Rediscovered in Manhattan Sheds Light on the Middle Phase of Human Evolution". The Anatomical Record 262: 341 - 343. 
Litherland, S., Márquez-Grant, N. \& Roberts, J. 2012. "Forensic Archaeology", dalam N. Márquez-Grant \& J. Roberts (eds.) Forensic Ecology Handbook: from Crime Scene to Court. Chichester: Blackwell Publishing Ltd. HIm. $23-48$.

López, A.M.G. \& Umańa, A.P. 2007. "Who Is Missing? Problems in the Application of Forensic Archaeology and Anthropology in Columbia's Conflict", dalam R. Ferlini (ed.) Forensic Archaeology and Human Rights Violations. Springfield: Charles C Thomas. HIm. 170 - 204.

Lovis, W.A. 1992. "Forensic Archaeology As Mortuary Anthropology". Social Science \& Medicine 34: 113 - 117.

Mark, J. 2010. "What Remains? Anti-communism, Forensic Archaeology, and the Retelling of the National Past in Lithuania and Romania". Past and Present 206 (S5): $276-300$.

Márquez, S., Mowbray, K., Sawyer, G.J., Jacob, T. \& Silvers, A. 2001. "New Fossil Hominid Calvaria from Indonesia - Sambungmacan 3". The Anatomical Record 262: 344 - 368.

Menez, L.L. 2005. "The Place of A Forensic Archaeologist at Acrime Scene Involving A Buried Body". Forensic Science International 152: 311 - 315.

Morse, D., Crusoe, D. \& Smith, H.G. 1976. "Forensic Archaeology". Journal of Forensic Sciences 21: 323 - 332.

Morse, D., Duncan, J. Stoutamire, J. 1983. Handbook of Forensic Archaeology and Anthropology. Tallahassee: Rose Printing.

Neave, R. 2000. "Forensic and Archaeological Reconstruction of the Human Face Upon the Skull", dalam M. Cox \& S. Mays (eds.) Human Osteology in Archaeology and Forensic Science. London: Greenwich Medical Media Ltd. HIm. $325-333$.

Owsley, D.W. 2001. "Why the Forensic Anthropologist Needs the Archaeologist". Historical Archaeology 35: 35 - 38.

Pate, F.D. 2005. "The Education of Archaeologists for the 21st Century". Australian Archaeology 61:1 - 6 .

Purwanti, S.H. 2013. Dari Bom Bali Hingga Tragedi Sukhoi: Keberhasilan DVI Indonesia dalam Mengungkap Berbagai Kasus. Jakarta: Rayyana Komunikasindo.

Rudovica,V., Viksna, A., Actins, A., Zarina, G., Gerhards, G. \& Lusens, M. 2011. Investigation of Mass Graves in the Churchyard of St.gertrude's, Riga, Latvia". Interdisciplinaria Archaeologica II: 39 - 46. 
Schultz, J.J. \& Dupras, T.L. 2008. "The Contribution of Forensic Archaeology to Homicide Investigations". Homicide Studies 12: 399 - 413.

Schats, R., Kootker, L.M., Hermsen, R., Davies, G.R. \& Hoogland, M.L.P. 2014. "The Alkmaar Mass Graves: A Multidisciplinary Approach to War Victims and Gunshot Trauma, dalam C. Knüsel \& M. Smith (eds.) The Routledge Handbook of the Bioarchaeology of Human Conflict. New York: Routledge. HIm. 455 - 472.

Scott, D.D. \& Connor, M. 2001. "The Role and Future of Archaeology in Forensic Science". Historical Archaeology 35: 101 - 104.

Sigler-Eisenberg, B. 1985 Forensic research: expanding the concept of applied archaeology. American Antiquity 50: 650 - 655.

Skinner, M. 2007. "Hapless in Afghanistan: Forensic Archaeology in A Political Maelstrom", dalam R. Ferlini (ed.) Forensic Archaeology and Human Rights Violations. Springfield: Charles C Thomas. HIm. $233-265$.

Skinner, M.F. 1987. "Planning the Archaeological Recovery from Recent Mass Graves". Forensic Science International 34: 267-287.

Skinner, M., Alempijevic, D. \& Djuric-Srejic, M. 2003. "Guidelines for International Forensic Bio-archaeology Monitors of Mass Grave Exhumations". Forensic Science International 134: 81 - 92.

Skinner, M. Bowie, K. 2009. "Forensic Anthropology: Canadian Content and Contributions", dalam S. Blau \& D.H. Ubelaker (eds.) Handbook of Forensic Archaeology and Anthropology. Walnut Creek: Left Coast Press. HIm. $87-103$.

Steadman, D.W., Basler, W., Hocbrein, M.J., Klein, D.F. \& Goodin, J.C. 2009. "Domestic Homicide Investigations: An Example from the United States", dalam S. Blau \& D.H. Ubelaker (eds.) Handbook of Forensic Archaeology and Anthropology. Walnut Creek: Left Coast Press. HIm. 351 - 362.

Steele, C. 2008. "Archaeology and the Forensic Investigation of Recent Mass Graves: Ethical Issues for A New Practice of Archaeology". Archaeologies 4: $414-428$.

Sterenberg, J. 2009. "Dealing with the Remains of Conflick: An International Response to Crimes Against Humanity, Forensic Recovery, Identification, and Repatriation in the Former Yugoslavia", dalam S. Blau \& D.H. Ubelaker (eds.) Handbook of Forensic Archaeology and Anthropology. Walnut Creek: Left Coast Press. HIm. 416 - 425.

Stover, E. \& Ryan, M. 2001. "Breaking Bread with the Dead". Historical Archaeology 35: 7 - 25.

Suriyanto, R.A. 2008. "Beberapa Ukuran Antropometris Lengan, Tangan, Tungkai dan Kaki untuk Penduga Tinggi Badan dalam Kasus-kasus 
Forensik: Kajian teoretis dan Rekomendasi Berperspektif Indonesia dalam Antropologi Forensik". Majalah Biomorfologi XXI: 41 - 56.

Suriyanto, R.A. 2012. "Mengenang Sang Perintis dan Tokoh Paleoantropologi Indonesia Prof. Dr. T. Jacob, M.S., M.D., D.Sc.: Paleoantropologi Indonesia dan Nasionalisme", dalam T. Koesbardiati \& R.A. Suriyanto (eds.) 3 Begawan Antropologi Biologis Indonesia: Ilmu, Aksi, dan Nasionalisme. Surabaya: Airlangga University Press. HIm. 3 - 84.

Thompson, T. 2001. "Legal and Ethical Considerations of Forensic Anthropological Research". Science \& Justice 41: 261 - 270.

2003. "Supply and Demand: the Shifting Expectations of Forensic Anthropology in the United Kingdom". Science \& Justice 43: $183-186$.

Tuller, H. \& Đurić, M. 2006. "Keeping the Pieces Together: Comparison of Mass Grave Excavation Methodology". Forensic Science International 156: 192 $-200$.

Tuller, H.H. 2012. "Mass Graves and Human Rights: Latest Development, Methods, and Lessons Learned", dalam D.C. Dirkmaat (ed.) $A$ Companion to Forensic Anthropology, $1^{\text {st }}$ ed. Chichester: Blackwell Publishing Ltd. HIm. $157-174$.

Ubelaker, D.H. 2009. "Historical Development of Forensic Anthropology: Perspectives from the United States", dalam S. Blau \& D.H. Ubelaker (eds.) Handbook of Forensic Archaeology and Anthropology. Walnut Creek: Left Coast Press. HIm. $76-86$.

Untoro, E. \& Atmadja, D.S. 2012. "Pengalaman Pemeriksaan Antropologi Forensik dalam Mengidentifikasi Sisa-sisa Tulang Belulang Tentara Jepang yang Gugur Pada Masa Perang Dunia ke-2 di Papua Barat dan Makassar, Indonesia (Periode 1999 - 2009)", dalam M.D. Artaria \& F.N. Ariningsih (eds.) Bunga Rampai Antropologi Ragawi: 80 Tahun Prof. Dr. Habil. Jozef Glinka SVD. Surabaya: Fakultas IImu Sosial dan IImu Politik Universitas Airlangga. HIm. 101 - I12.

Wright, R. \& Hanson, I. 2009. "How to Do Forensic Archaeology Under the Auspices of the United Nations and Other Larger Organizations", dalam S. Blau \& D.H. Ubelaker (eds.) Handbook of Forensic Archaeology and Anthropology. Walnut Creek: Left Coast Press. HIm. 468 - 478.

Wright, R., Hanson, I. \& Sterenberg, J. 2005. "The Archaeology of Mass Graves", dalam J. Hunter \& M. Cox (eds.) Forensic Archaeology: Advances in Theory and Practice. New York: Routledge. Hal.: $137-158$. 

(1) 